\title{
New Dietary Records for Three Cuban Snakes in the Genus Tropidophis (Tropidophiidae), with Comments on Possible Niche Partitioning by Cuban Tropes
}

\author{
Tomás M. Rodríguez-Cabrera ${ }^{1}$, Ansel Fong G. ${ }^{2}$, and Javier Torres ${ }^{3}$ \\ 1Sociedad Cubana de Zoología, La Habana 12000, Cuba (tomasmichel.rodriguez@gmail.com) \\ ${ }^{2}$ Centro Oriental de Ecosistemas y Biodiversidad (BIOECO), Museo de Historia Natural “Tomás Romay,” Santiago de Cuba 90100, Cuba (ansel@bioeco.cu) \\ ${ }^{3}$ Department of Ecology and Evolutionary Biology, The University of Kansas, Kansas 66045, USA (javiertorres@ku.edu).
}

$\mathrm{T}$ he diets of West Indian snakes in the genus Tropidophis (Tropidophiidae) are poorly known (see Henderson and Powell 2009 for a review). Dietary information exists only for 15 of the 27 West Indian species and most of it consists of isolated records (Henderson and Powell 2009; Table 1). The available data suggest that they feed mostly on ectotherms such as anurans and lizards, although the largest species such as the Hispaniolan Trope (T. haetianus) (to $>550$ $\mathrm{mm}$ SVL) and the Giant Trope (T. melanurus) (to $>1,000$ $\mathrm{mm}$ SVL) may consume endotherms (e.g., small rodents and birds) (e.g., Henderson and Powell 2009; Rodríguez-Cabrera et al. 2017) (Table 1). Cuba is the center of diversification in the genus, with 16 currently recognized endemic species (e.g., Hedges et al. 2002; Domínguez et al. 2006; Uetz et al. 2020). However, the feeding habits of most Cuban species are virtually unknown. Herein we provide the first dietary records for the Gracile Banded Trope (T. wrighti) and the Yellow Banded Trope (T. semicinctus), and the second dietary record for the Broad-banded Trope (T. feicki). We also provide a review of the prey of West Indian species and comment on possible niche partitioning in Cuban species.

At $1030 \mathrm{~h}$ on 10 December 1997, we found an adult female T. wrighti (274 $\mathrm{mm} \mathrm{SVL}$ ) with a stomach bulge at Piedra La Vela, Yateras Municipality, Guantánamo Province $\left(20^{\circ} 24^{\prime} 05.0^{\prime \prime} \mathrm{N}, 7^{\circ} 56^{\prime} 23.0^{\prime \prime} \mathrm{W} ; 680 \mathrm{~m}\right.$ asl). The snake was under the bark of a pine tree $0.6 \mathrm{~m}$ above the ground in a reforested pinewood. After being placed in a container, the snake regurgitated a female Cuban Dark Bark Anole (Anolis argillaceus) (33 $\mathrm{mm} \mathrm{SVL}$ ). The lizard apparently had been captured the night before since signs of digestion were not evident. The snake was deposited in the herpetological collection of the Centro Oriental de Ecosistemas y Biodiversidad (BIOECO; voucher: BSC.H-1460). This is the first confirmed dietary record for the Gracile Banded Trope.

At $1115 \mathrm{~h}$ on 30 October 2014, we found a juvenile male T. semicinctus (165 mm SVL) with a stomach bulge (Fig. 1) at El Nicho, Cumanayagua Municipality, Cienfuegos Province $\left(22^{\circ} 01^{\prime} 50.0^{\prime \prime} \mathrm{N}, 80^{\circ} 07^{\prime} 16.0^{\prime \prime} \mathrm{W} ; 430 \mathrm{~m}\right.$ asl). The snake was
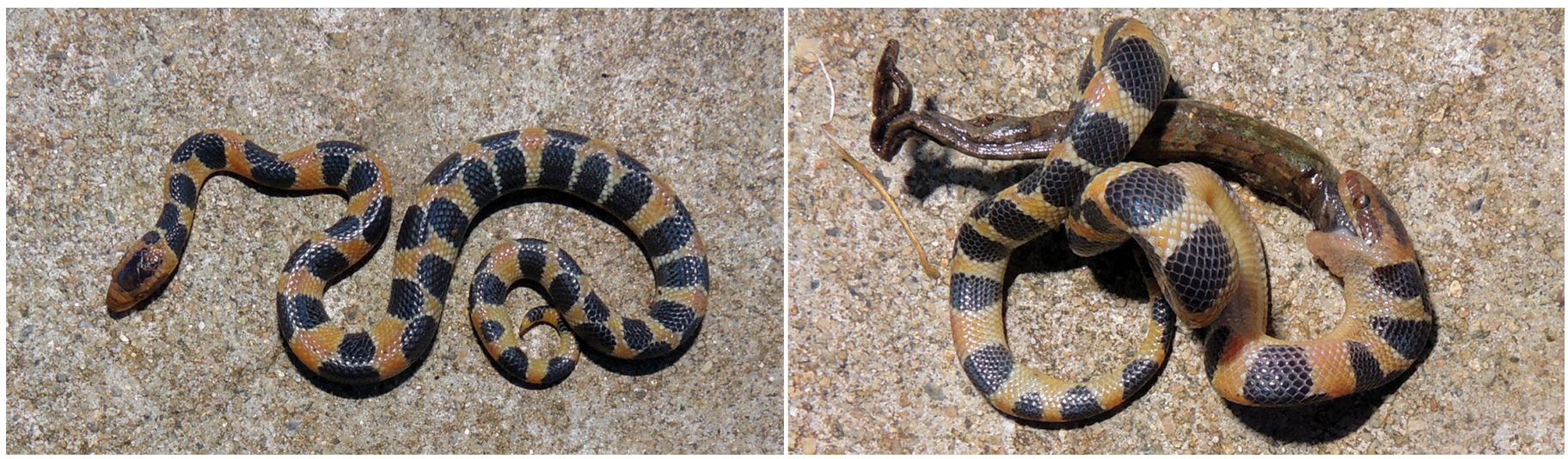

Fig. 1. A juvenile male Yellow-banded Trope (Tropidophis semicinctus) from El Nicho in Cienfuegos Province, freshly captured with a stomach bulge (left) and regurgitating a Cuban Brown Anole (Anolis sagrei) (right) after palpation of the abdomen. Photographs (C) T.M. Rodríguez-Cabrera. 
Table 1. Prey reported for West Indian snakes of the genus Tropidophis (Tropidophiidae) in nature. An asterisk $\left({ }^{*}\right)$ indicates an unsuccessful predation event. Two asterisks $(* *)$ indicate probable incidental ingestion.

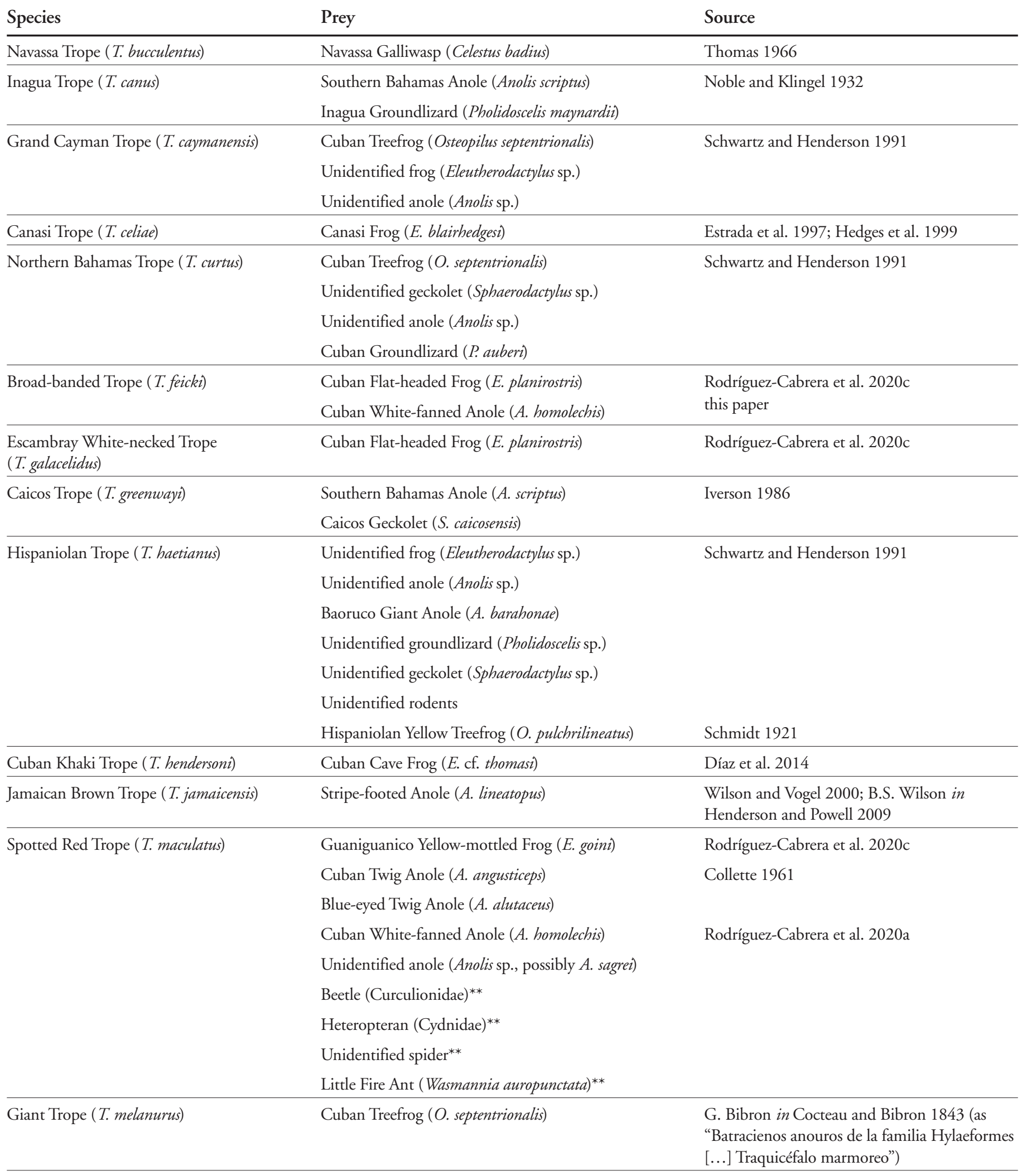




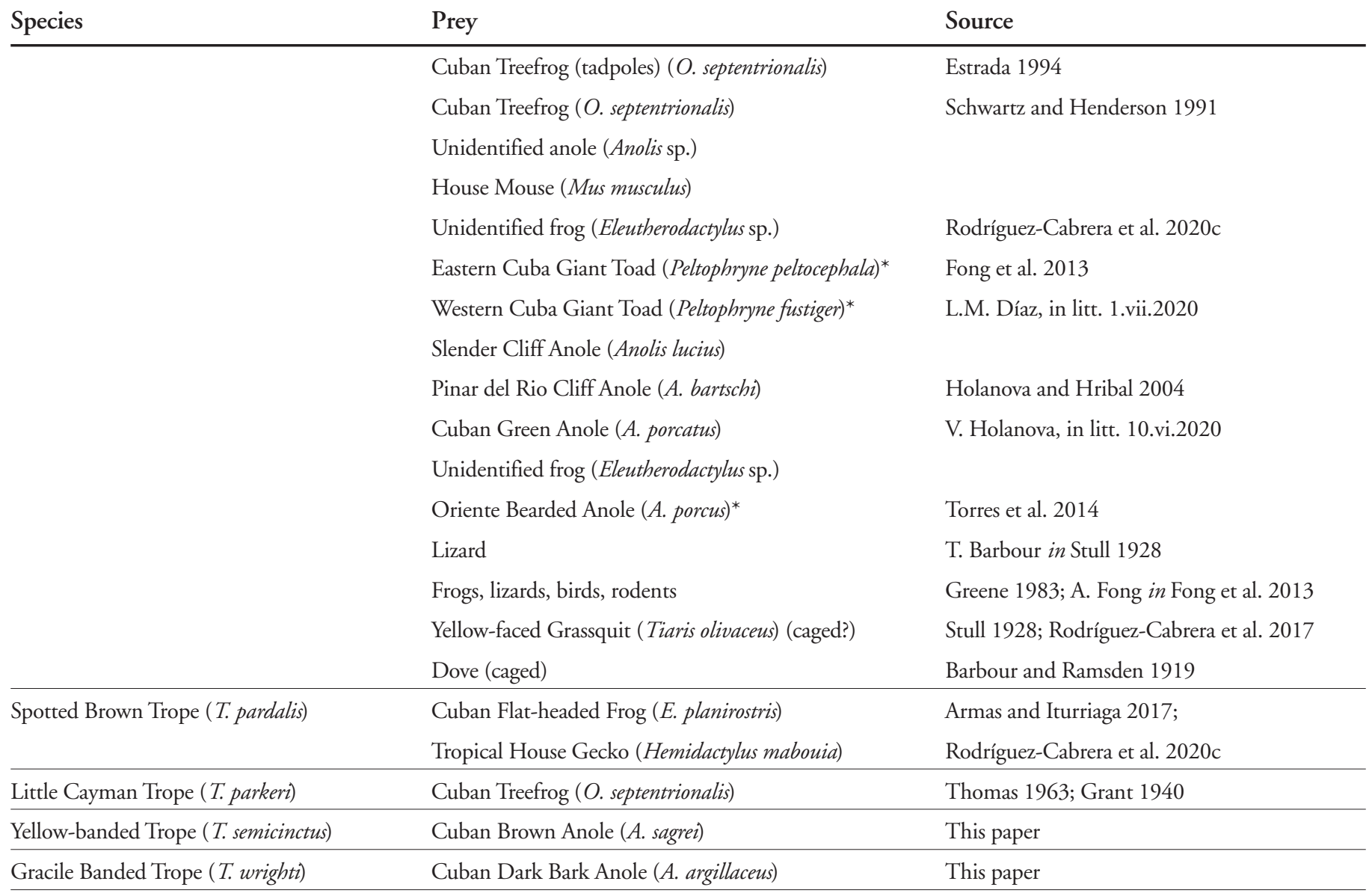

under a rock in a secondary grassland by a road in a rural area. We forced regurgitation by palpation of the abdomen in order to obtain the prey item for identification and measurements. The prey item was a juvenile Cuban Brown Anole ( $A$. sagrei) (32 $\mathrm{mm} \mathrm{SVL}$ ), with indications of digestion on the head (Fig. 1). The snake was released at the site of its capture and the prey item was preserved in $75 \%$ ethanol and depos- ited in the personal collection of the senior author. This is the first dietary record for the Yellow Banded Trope.

At 1913 h on 21 December 2016, we found an adult female $T$. feicki (355 mm SVL) swallowing an adult female Cuban White-fanned Anole (A. homolechis) ( $45 \mathrm{~mm} \mathrm{SVL),} \mathrm{near}$ the Santa Cruz River in the Sierra del Rosario Mountain Range, San Cristóbal Municipality, Artemisa Province (2244'58.2"N,
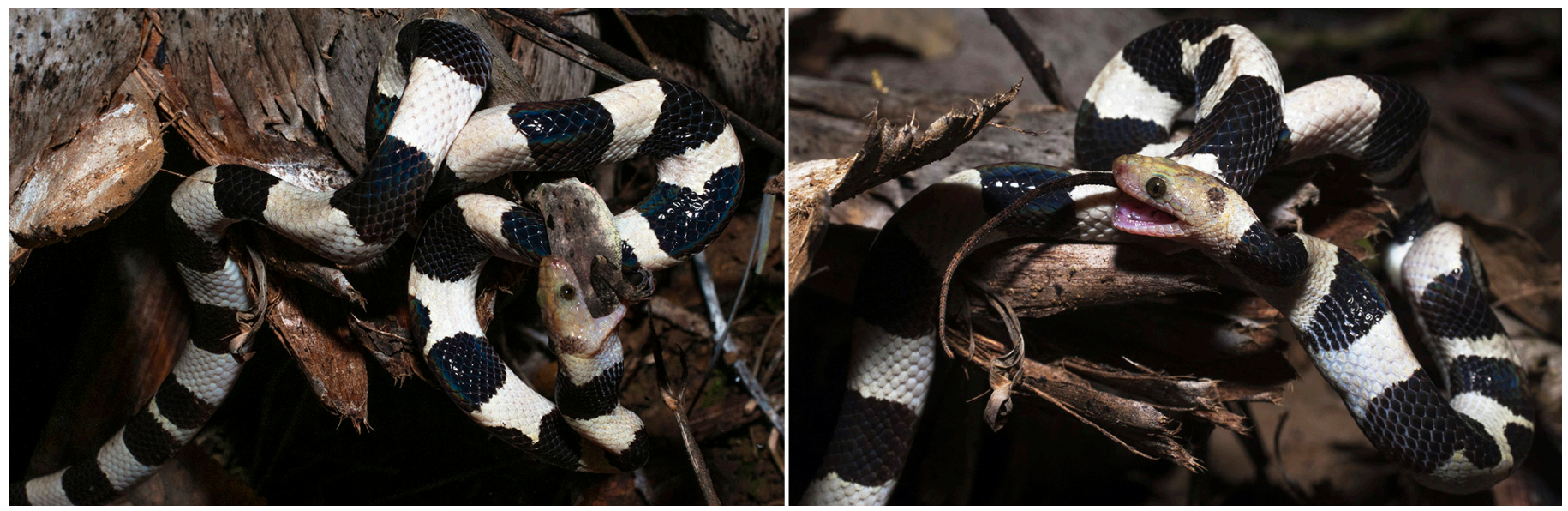

Fig. 2. A female Broad-banded Trope (Tropidophis feicki) from the Santa Cruz River in Artemisa Province, swallowing an adult female Cuban White-fanned Anole (Anolis homolechis) when first seen (left) and with ingestion nearly complete five minutes later (right). Photographs (C) Raimundo López-Silvero (left) and Rosario Domínguez (right). 
$83^{\circ} 08^{\prime} 59.3^{\prime \prime W} ; 160 \mathrm{~m}$ asl). When first seen, the snake had swallowed the head and neck of the anole (Fig. 2). Complete ingestion ended five minutes later at $1918 \mathrm{~h}$ (Fig. 2). The predation event took place on a fallen dead palm frond about $0.2 \mathrm{~m}$ above a limestone substrate at the edge of a semi-deciduous forest. We forced regurgitation to obtain the prey item for measurements. The snake was released at the site of its capture and the prey item was preserved in $75 \%$ ethanol and deposited in the personal collection of the senior author. This is the second dietary record for the Broad-banded Trope (Table 1).

Anoles are diurnal and the prey species reported above are mostly arboreal (e.g., Rodríguez 1999; Henderson and Powell 2009; Losos 2009). This suggests that these three snakes accessed their sleeping prey by employing an activeforaging mode at night. All three of these snakes have slender bodies and have been reported foraging in vegetation at night (Schwartz and Henderson 1991; Hedges 2002; Henderson and Powell 2009; Díaz et al. 2014). Tropidophis feicki also has been observed foraging in caves and on rocky cliffs and in associated vegetation at night (Schwartz 1957; Schwartz and Henderson 1991; García-Padrón et al. 2020; RodríguezCabrera et al. 2020b; Fig. 3). Díaz et al. (2014) found as many as 20 Gracile Banded Tropes foraging on thin branches from $0.5-5.0 \mathrm{~m}$ above the ground in a single night (see also Henderson and Powell 2009 for a review). Díaz et al. (2014) also mentioned sleeping anoles as prey of $T$. wrighti, but they did not provide any details. Rodríguez-Cabrera et al. (2020a) described a similar foraging strategy in Spotted Red Tropes (T. maculatus), another gracile species from western and central Cuba that also feeds on anoles (Fig. 4; Table 1). We have repeatedly observed $T$. wrighti and $T$. semicinctus foraging in the vegetation at night at several localities in eastern and central Cuba, respectively (Fig. 4). We also have seen captive snakes of all of these species actively forage at night.

In addition to similarities in body shapes and foraging strategies, many of these gracile tropes occupy similar habitats. Tropidophis wrighti, T. maculatus, and T. semicinctus have relatively wide distributions and occupy a wide range of habitats from sea level to over $900 \mathrm{~m}$ (Rodríguez et al. 2010, 2013; Blanco and Fong 2011; Henderson and Powell 2009). During the day they shelter under rocks and tree bark, apparently emerging to forage in vegetation at night (Henderson and Powell 2009; Blanco and Fong 2011). These three species even occur in altered suburban and urban areas, and at least $T$. semicinctus has been found to be relatively common under rocks in pastures with isolated shrubs (authors, pers. obs.). On the contrary, T. feicki seems to have more specific habitat requirements, occurring almost exclusively in mesic limestone areas covered by primary forest in western and central Cuba (Schwartz and Henderson 1991; RodríguezCabrera et al. 2020b).

The three snakes described herein in most cases co-occur with other species of Tropidophis. Giant Tropes and Cuban Dusky Tropes ( $T$. fuscus) potentially coexist with $T$. wrighti in the Sagua-Baracoa Massif where Piedra La Vela is located (e.g., Rodríguez et al. 2013). Other species observed coexisting sympatrically with $T$. semicinctus at El Nicho were T. melanurus and the Escambray White-necked Trope ( $T$. galacelidus) (Torres and Rodríguez-Cabrera 2020; T.M. Rodríguez-Cabrera, pers. obs.). In the area around the Santa Cruz River, other species observed coexisting sympatrically or parapatrically with T. feicki were T. melanurus, T. maculatus, and the Spotted Brown Trope (T. pardalis). This coexistence of species with different body shapes is suggestive of structural habitat niche partitioning.

Apparently, well-defined species assemblages of Tropidophis are repeated across the Cuban Archipelago (Fig. 5). These vary in species composition according to the region but not in body shapes of the species that constitute them (see Rodríguez et al. 2013 for a review on species distributions). Such assemblages seem to be composed of three to four species at the most, each belonging to one of three basic ecotypes: (1) generalist, (2) terrestrial, and (3) semi-arboreal (see also Díaz et al. 2014; Rodríguez-Cabrera et al. 2016; Torres and Rodríguez-Cabrera 2020) (Fig. 5). The generalist ecotype is always represented by the Giant Trope, the largest species,

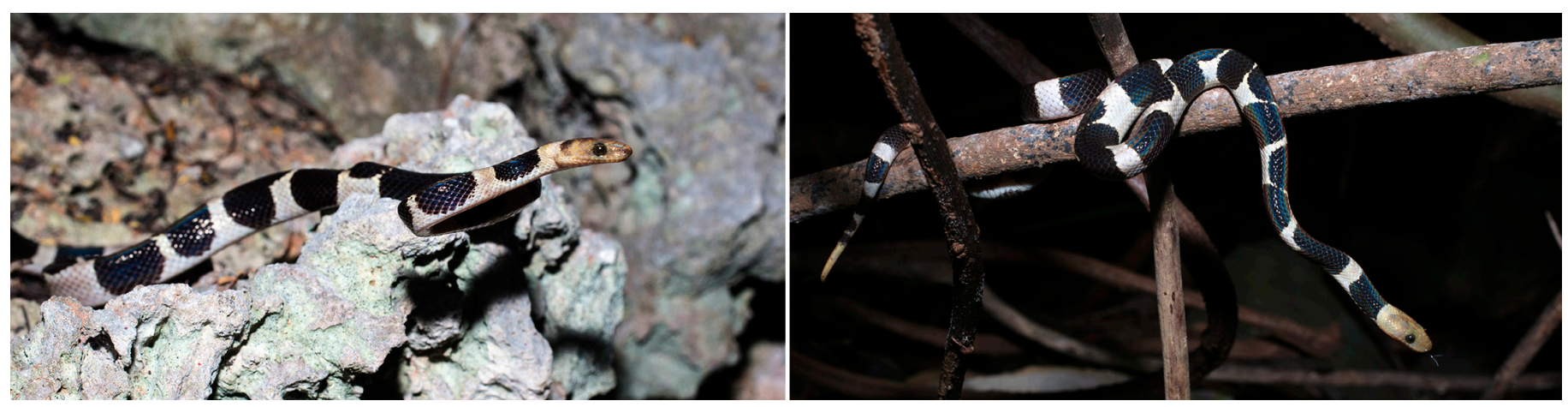

Fig. 3. Tropidophis feicki is a gracile snake that is frequently observed foraging on limestone (left) and in the associated vegetation (right) at night. Photographs (C) Raimundo López-Silvero. 


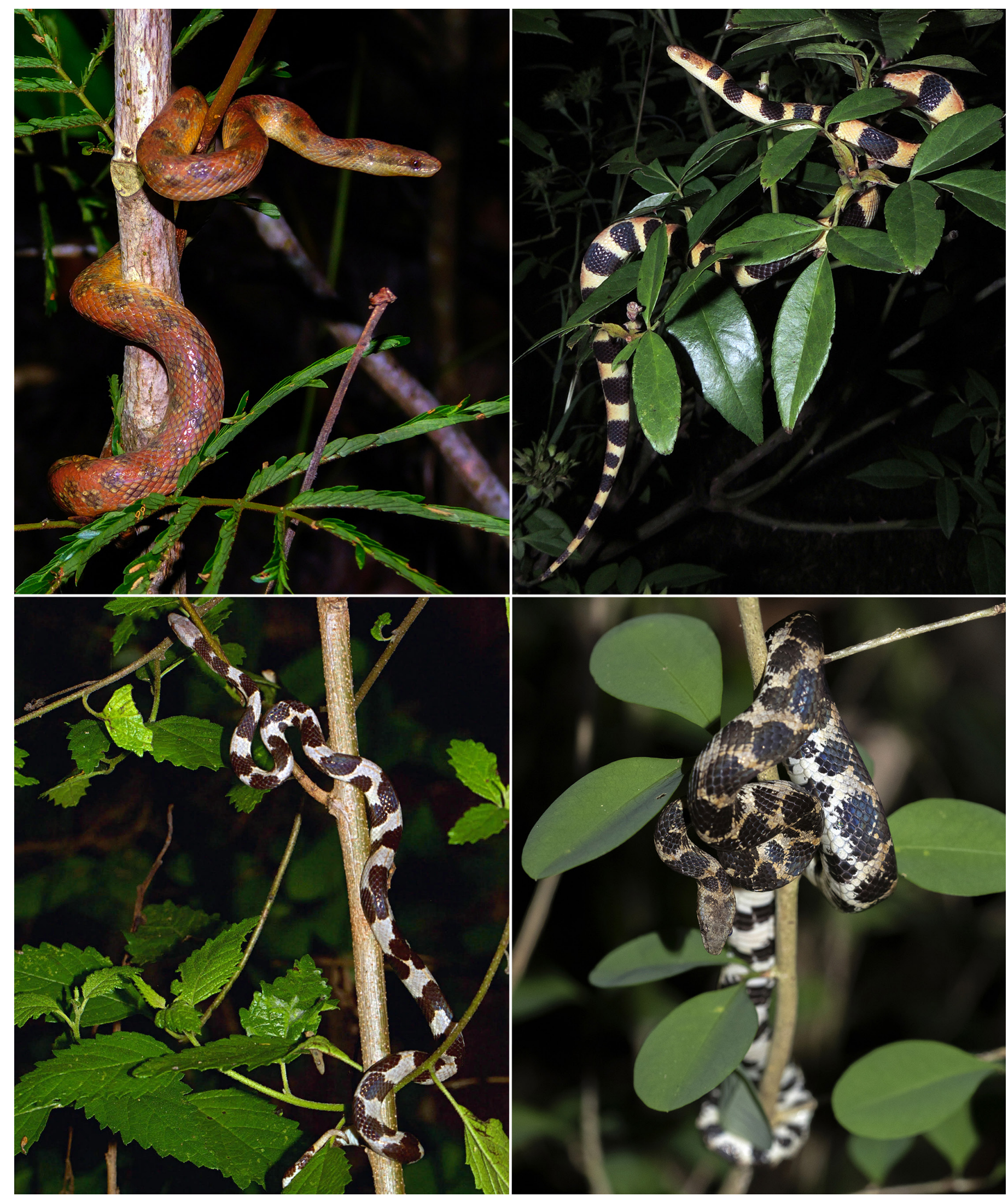

Fig. 4. Gracile species of Cuban tropes (Tropidophis) are frequently observed foraging in vegetation at night and most seem to prey on sleeping anoles, which suggests that they are active foragers. Spotted Red Trope (T. maculatus) (upper left), Yellow-banded Trope (T. semicinctus) (upper right), Gracile Banded Trope (T. wrighti) (lower left), and Sancti Spiritus Trope (T. spiritus) (lower right). Photographs (C) Rolando Teruel, T.M. Rodríguez-Cabrera, Ruben Marrero, and Aslam I. Castellón. 


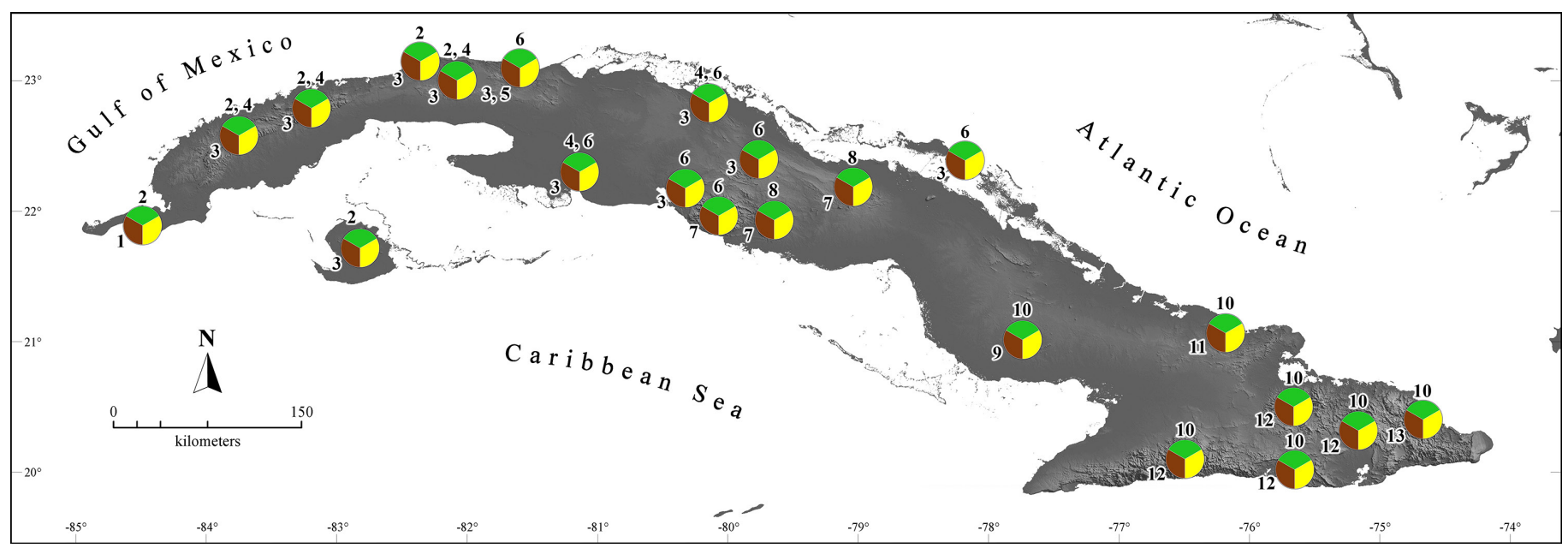

Fig. 5. Composition of species assemblages of Tropidophis in Cuba. Yellow represents the generalist ecotype (always T. melanurus), brown the terrestrial ecotype, and green the semi-arboreal ecotype. Species are: (1) T.xanthogaster, (2) T. maculatus, (3) T. pardalis, (4) T. feicki, (5) T. celiae, (6) T. semicinctus, (7) T. galacelidus, (8) T. spiritus, (9) T. nigriventris, (10) T. wrighti, (11) T. hendersoni, (12) T. pilsbryi, and (13) T. fuscus. Tropidophis hardyi and T. morenoi are not included because their taxonomic status is in need of revision since they might be conspecific with some of the species listed above.

which is widely distributed in Cuba and has the most varied diet (Rodríguez et al. 2013; Table 1). The terrestrial ecotype is represented by stout, small to medium-sized species (to ca. 400 mm SVL) (i.e., Canasí Trope, T. celiae; Cuban Dusky Trope; Escambray White-necked Trope; Escambray Smallheaded Trope, T. hardyi; Cuban Khaki Trope, T. hendersoni; Dark-bellied Trope, T. nigriventris; Spotted Brown Trope; Oriente White-necked Trope, T. pilsbryi, and Guanahacabibes Trope, T. xanthogaster), all of whose diets are little known, but at least some of them have been reported to feed on frogs of the genus Eleutherodactylus and lizards (Table 1). The semiarboreal ecotype is represented by gracile medium-sized species (to ca. $500 \mathrm{~mm}$ SVL) (i.e., Broad-banded Trope; Spotted Red Trope; Zebra Trope, T. morenoi; Yellow-banded Trope; Sancti Spiritus Trope, T. spiritus, and Gracile Banded Trope), all of which apparently feed on anoles and seem to use an active-foraging mode (see above). Díaz et al. (2014) also suggested that microhabitat segregation existed between the gracile and semi-arboreal T. wrighti and the stouter and largely ground-dwelling species, T. hendersoni and T. melanurus, north of Holguin Province in eastern Cuba. A fourth variant of the semi-arboreal ecotype, always represented by $T$. feicki, occurs in some localities in western and central Cuba (e.g., Rodríguez-Cabrera et al. 2020b). It can co-occur with either T. maculatus or T. semicinctus (Fig. 5). Assuming that those two species might compete with $T$. feicki is reasonable, since they all have similar body shapes (e.g., Hedges 2002) and use similar foraging strategies. However, according to our observations, they seem to be parapatric. Tropidophis feicki occupies densely forested areas on limestone substrates, whereas T. maculatus and T. semicinctus occupy areas with more open vegetation, such as grasslands, scrublands, ecotonal, and/or secondary vegetation. This parapatric co-occurrence between $T$. feicki and T. maculatus or T. semicinctus can be observed in several localities across the Guaniguanico Mountain Range in western Cuba and at the "Mogotes de Jumagua" Ecological Reserve in central Cuba, respectively (e.g., Rivalta-G. et al. 2013; Rodríguez-Cabrera et al. 2020b; T.M. Rodríguez-Cabrera, pers. obs.) (Fig. 5). Tropidophis maculatus and T. semicinctus seem to be mutually exclusive, with only a small overlap, if any, in their distributions (e.g., Rodríguez et al. 2013). A similar exclusion seems to occur between the gracile species inhabiting the Guamuhaya Massif in south-central Cuba. This mountain range is divided by the Agabama River Basin and forms two main topographical units: the Trinidad Range in the west and the Sancti Spiritus Range in the east (e.g., MateoRodríguez and Acevedo-González 1989). The gracile species occurring in the Trinidad Range is T. semicinctus, which coexists with T. melanurus and T. galacelidus (e.g., Rodríguez et al. 2013; Torres and Rodríguez-Cabrera 2020; T.M. RodríguezCabrera, pers. obs.). In the Sancti Spiritus Range, the assemblage is essentially the same, except that the gracile species is replaced by T. spiritus (e.g., Rodríguez et al. 2013; Torres and Rodríguez-Cabrera 2020; Figs. 4 and 5). Two terrestrial species, T. pardalis and T. celiae, are known to co-occur at least at Canasí, on the northern coast of Mayabeque Province. The only two specimens of $T$. celiae collected at this locality were found on bare limestone along the shoreline (Hedges et al. 1999; Torres et al. 2016), whereas the single specimen of $T$. pardalis was found farther inland in a stand of Sea Grapes (J. Torres, unpubl. data). However, given the wide size range of terrestrial species, additional observations are needed to determine if niche partitioning exists within that ecotype.

Morphological divergence in body shapes probably plays an important role in niche partitioning by species of Tropidophis, allowing coexistence of different species. 
Niche partitioning associated with body shapes has been found in other West Indian taxa such as frogs of the genus Eleutherodactylus, lizards of the genus Anolis, and snakes of the genus Chilabothrus (e.g., Henderson et al. 1987; Losos 2009; Reynolds et al. 2016; Rodríguez-Cabrera et al. 2016; Dugo-Cota et al. 2019). Additionally, species with similar body plans might have evolved physiological and behavioral traits allowing macrohabitat segregation (e.g., Williams 1983). Similar ecotypes of Tropidophis apparently do not coexist, which probably is attributable to competitive exclusion (e.g., Gause 1934, 1935; Connell 1961). Nonetheless, in some recent compilations on the distributions of Tropidophis in Cuba (e.g., Rodríguez et al. 2013), this principle seems to be contradicted, as more than one species with the same body plan have been reported from the same localities. However, some of those records might represent misidentifications, since some of these species are phenotypically similar (e.g., Tolson and Henderson 1993; Hedges 2002, 2020). This apparent habitat segregation and morphological and behavioral divergence of species in the genus Tropidophis has not been observed elsewhere in the West Indies, where multiple species do not co-occur (e.g., Schwartz and Henderson 1991; Tolson and Henderson 1993; Powell and Henderson 2012; Díaz et al. 2014; Rodríguez-Cabrera et al. 2016). The only island with multiple species other than Cuba is Jamaica, with three species, but the distributions of those species do not overlap (e.g., Schwartz and Henderson 1991; Tolson and Henderson 1993; Hedges 2020). Additional studies are needed to test hypotheses related to niche partitioning, niche overlap, and the evolution of body shapes in the Cuban assemblages of Tropidophis.

\section{Acknowledgements}

The Mohamed bin Zayed Species Conservation Fund (project No. 170515264, to the senior author), the Earthwatch Institute, the Wildlife Conservation Society (WCS), the Instituto de Ecología y Sistemática, and the Jardín Botánico de Cienfuegos provided funding for equipment and expeditions in south-central Cuba. Maikel Cañizares, Lucía Hechevarría, and Natalia Rossi arranged several Earthwatch expeditions to the "Lomas de Banao" Ecological Reserve (Project: "Mapping Biodiversity in Cuba"). Tomás García and family from the Santa Cruz River in western Cuba provided logistical support and accommodations. We thank Rolando Teruel, Julio D. León, Raimundo López-Silvero, Rosario Domínguez, Ruben Marrero, Aslam I. Castellón, Andre Baumgarten, Aliesky del Río, and many Earthwatch volunteers for assistance in the field and/or for photographs. Veronika Holanova kindly provided additional information related to one of her papers (Holanova and Hribal 2004). Luis M. Díaz shared unpublished data and provided helpful comments on this manuscript.

\section{Literature Cited}

Armas, L.F. de and M. Iturriaga. 2017. Depredación de Hemidactylus mabouia (Squamata: Gekkonidae) por Tropidophis pardalis (Serpentes: Tropidophiidae). Novitates Caribaea 11: 99-102.

Barbour, T. and C.T. Ramsden. 1919. The herpetology of Cuba. Memoirs of the Museum of Comparative Zoölogy 47: 71-213.

Blanco Ojeda, A. and A. Fong G. 2011. Hábitat, actividad diurna y morfometría de cuatro especies de ofidios (Reptilia: Squamata) de Cuba. Novitates Caribaea 4: 91-99.

Cocteau, J.T. and G. Bibron. 1843. Reptiles, pp. 1-142. In: R. de la Sagra (ed.), Historia Física, Politica y Natural de la Isla de Cuba. Segunda Parte, Historia Natural. Tomo IV. Reptiles y Peces. Arthus Bertrand, Paris, France.

Collette, B.B. 1961. Correlations between ecology and morphology in anoline lizards from Havana, Cuba and southern Florida. Bulletin of the Museum of Comparative Zoology 125: 137-162.

Connell, J.H. 1961. The influence of interspecific competition and other factors on the distribution of the barnacle Chthamalus stellatus. Ecology 42: 710-723.

Díaz, L.M., A. Cádiz, S. Villar, and F. Bermudez. 2014. Notes on the ecology and morphology of the Cuban Khaki Trope, Tropidophis hendersoni Hedges and Garrido (Squamata: Tropidophiidae), with a new locality record. Reptiles \& Amphibians 21:116-119.

Domínguez, M., L.V. Moreno, and S.B. Hedges. 2006. A new snake of the genus Tropidophis (Tropidophiidae) from the Guanahacabibes Peninsula of Western Cuba. Amphibia-Reptilia 27: 427-432.

Dugo Cota, Á., C. Vilà, A. Rodríguez, and A. Gonzalez Voyer. 2019. Ecomorphological convergence in Eleutherodactylus frogs: A case of replicate radiations in the Caribbean. Ecology Letters 22: 884-893.

Estrada, A.R. 1994. Herpetofauna de la Cuenca Banao-Higuanojo, Sancti Spíritus, Cuba. Revista de la Academia Colombiana de Ciencias 19: 353-360.

Estrada, A.R., L.M. Díaz, and A. Rodríguez. 1997. Nueva especie de Eleutherodactylus (Anura: Leptodactylidae) del litoral norte de La Habana, Cuba. Revista Española de Herpetología 11: 19-24.

Fong G., A., I. Bignotte Giró, and K. Maure García. 2013. Unsuccessful predation on the toad Peltophryne peltocephala (Bufonidae) by the Cuban snake Tropidophis melanurus (Tropidophiidae). Herpetology Notes 6: 73-75.

García-Padrón, L.Y., J. Torres [López], and M. Boligan Expósito. 2020. Aberrant body markings in the Cuban banded dwarf boa, Tropidophis feicki (Squamata: Tropidophiidae). The Herpetological Bulletin 152: 38-39.

Gause, G.F. 1934. The Struggle for Existence. Williams \& Wilkins, Baltimore, Maryland, USA (reprinted in 1964 by Hafner, New York, New York, USA).

Gause, G.F. 1935. Experimental demonstration of Volterra's periodic oscillation in the numbers of animals. Journal of Experimental Biology 12: 44-48.

Grant, C. 1940. The herpetology of the Cayman Islands. Bulletin of the Institute of Jamaica, Science Series 2: iv + 65 pp.

Greene, H.W. 1983. Dietary correlates of the origin and radiation of snakes. American Zoologist 23: 431-441.

Hedges, S.B. 2002. Morphological variation and the definition of species in the snake genus Tropidophis (Serpentes: Tropidophiidae). Bulletin of the Natural History Museum, London (Zoology) 68: 83-90.

Hedges, S.B. 2020. Caribherp: West Indian Amphibians and Reptiles. <http:// www.caribherp.org>.

Hedges, S.B., A.R. Estrada, and L.M. Díaz. 1999. New snake (Tropidophis) from western Cuba. Copeia 1999: 376-381.

Henderson, R.W. and R. Powell. 2009. Natural History of West Indian Amphibians and Reptiles. University Press of Florida, Gainesville, Florida, USA.

Henderson, R.W., T.A. Noeske-Hallin, J.A. Ottenwalder, and A. Schwartz. 1987. On the diet of the boa Epicrates striatus on Hispaniola, with notes on E. fordi and E. gracilis. Amphibia-Reptilia 8: 251-258.

Holanova, V. and J. Hribal, 2004. Dos anolis cubanos: Anolis bartschi y Anolis lucius. Reptilia 47: 62-68.

Iverson, J.B. 1986. Notes on the natural history of the Caicos Islands Dwarf Boa, Tropidophis greenwayi. Caribbean Journal of Science 22: 191-198.

Losos, J.L. 2009. Lizards in an Evolutionary Tree: Ecology and Adaptive Radiation of Anoles. University of California Press, Berkeley, California, USA.

Mateo-Rodríguez, J. and M. Acevedo-González. 1989. Regionalización físico-geográfica 5. 1:3000 000, pp. XII.2.1. In: G. Oliva (ed.), Nuevo Atlas Nacional de 
Cuba. Academia de Ciencias de Cuba and Instituto Cubano de Geodesia y Cartografía, Instituto de Geografía Nacional de España, Madrid, Spain.

Noble, G.K. and G.C. Klingel. 1932. The reptiles of Great Inagua Island, British West Indies. American Museum Novitates 549: 1-25.

Powell, R. and R.W. Henderson (eds.). 2012. Island lists of West Indian amphibians and reptiles. Bulletin of the Florida Museum of Natural History 51: 85-166.

Reynolds, R.G., D.C. Collar, S.A. Pasachnik, M.L. Niemiller, A.R. Puente-Rolón, and L.J. Revell. 2016. Ecological specialization and morphological diversification in Greater Antillean boas. Evolution 70: 1882-1895.

Rivalta-G[onzález], V., A. González-C., and L. Rodríguez-S[chettino]. 2013. Colección herpetológica del Instituto de Ecología y Sistemática, La Habana, Cuba. Familia Tropidophiidae, género Tropidophis. Revista Colombiana de Ciencia Animal 5: 282-300.

Rodríguez-Cabrera, T.M., R. Marrero [Romero], and J. Torres [López]. 2016. An overview of the past, present and future of the Cuban boa, Chilabothrus angulifer (Squamata: Boidae): A top terrestrial predator on an oceanic island. Reptiles \& Amphibians 23: 152-168.

Rodríguez-Cabrera, T.M., J. Rosado, R. Marrero [Romero], and J. Torres [López]. 2017. Birds in the diet of snakes in the genus Tropidophis (Tropidophiidae): Do prey items in museum specimens always reflect reliable data? Reptiles \& Amphibians 24: 61-64.

Rodríguez-Cabrera, T.M., L.Y. García-Padrón, and J. Torres [López]. 2020a. New dietary records for the Cuban Spotted Red Trope, Tropidophis maculatus (Squamata: Tropidophiidae). Caribbean Herpetology 73: 1-2.

Rodríguez-Cabrera, T.M., J. Torres [López], and E. Morell Savall. 2020b. Easternmost record of the Cuban Broad-banded Trope, Tropidophis feicki (Squamata: Tropidophiidae). Caribbean Herpetology 71: 1-3

Rodríguez-Cabrera, T.M., L.Y. García-Padrón, E. Morell Savall, and J. Torres [López]. 2020c. Predation on direct-developing frogs (Eleutherodactylidae: Eleutherodactylus) in Cuba: New cases and a review. Reptiles \& Amphibians 27: 161-168.

Rodríguez Schettino, L. (ed.). 1999. The Iguanid Lizards of Cuba. University Press of Florida, Gainesville, Florida.

Rodríguez Schettino, L., V. Rivalta González, and E. Pérez Rodríguez. 2010. Distribución regional y altitudinal de los reptiles de Cuba. Poeyana 498: 11-20.
Rodríguez Schettino, L., C.A. Mancina, and V. Rivalta González. 2013. Reptiles of Cuba: Checklist and geographic distribution. Smithsonian Herpetological Information Service 144: 1-96.

Schmidt, K.P. 1921. Notes on the herpetology of Santo Domingo. Bulletin of the American Museum of Natural History 44: 7-20.

Schwartz A. 1957. A new species of boa (genus Tropidophis) from western Cuba. American Museum Novitates 1839: 1-8.

Schwartz, A. and R.W. Henderson. 1991. Amphibians and Reptiles of the West Indies. Descriptions, Distributions, and Natural History. University of Florida Press, Gainesville, Florida, USA.

Stull, O.G. 1928. A revision of the genus Tropidophis. Occasional Papers of the Museum of Zoology, University of Michigan 195: 1-49.

Thomas, R. 1963. Cayman Islands Tropidophis (Reptilia, Serpentes). Breviora 195: 1-8.

Thomas, R. 1966. A reassessment of the herpetofauna of Navassa Island. Journal of the Ohio Herpetological Society 5: 73-89.

Tolson, P.J. and R.W. Henderson. 1993. The Natural History of West Indian Boas. R\&A Publishing Limited, Somerset, England.

Torres [López], J. and T.M. Rodríguez-Cabrera. 2020. Diurnal refuge sharing between species of Cuban snakes of the genus Tropidophis (Squamata: Tropidophiidae). Caribbean Herpetology 74: 1-2.

Torres [López], J., C. Pérez-Penichet, and O.[J.] Torres [Fundora]. 2014. Predation attempt by Tropidophis melanurus (Serpentes, Tropidophiidae) on Anolis porcus (Sauria, Dactyloidae). Herpetology Notes 7: 527-529.

Torres López, J., T.M. Rodríguez-Cabrera, R. Marrero Romero, O.J. Torres Fundora, and P. Gutiérrez Macías. 2016. Comments on the critically endangered Canasí Trope (Tropidophis celiae, Tropidophiidae): Neonates, ex situ maintenance, and conservation. Reptiles \& Amphibians 23: 82-87.

Uetz, P., P. Freed, and J. Hošek (eds.). 2020. The Reptile Database. <http://www. reptile-database.org>.

Williams, E.E. 1983. Ecomorphs, faunas, island size, and diverse end points in island radiations of Anolis, pp. 327-370. In: R.B. Huey, E.R. Pianka, and T.W. Schoener (eds.), Lizard Ecology: Studies of a Model Organism. Harvard University Press, Cambridge, Massachusetts, USA.

Wilson, B.S. and P. Vogel. 2000. A survey of the herpetofauna of the Hellshire Hills, Jamaica, including the rediscovery of the Blue-tailed Galliwasp (Celestus duquesneyi Grant). Caribbean Journal of Science 36: 244-249. 